\title{
Shared Leadership Practices: Do Secondary School Heads in Botswana Matter?
}

\author{
Luke Moloko Mphale (Corresponding author) \\ Dept. of Primary Education, University of Botswana \\ Private Bag 00702, Gaborone, Botswana
}

Tel: 267-355-4918Ｅ-mail: mphaleluke@yahoo.com

Received: March 24, 2015 Accepted: April 16, 2015 Published: May 16, 2015

doi:10.5296/jse.v5i2.7307 URL: http://dx.doi.org/10.5296/jse.v5i2.7307

\begin{abstract}
The purpose of the study was to investigate Botswana secondary school heads' perceptions on shared leadership practices. The study used a survey design. Three research questions guided the study. Data were collected through an individual structured questionnaire which was validated. The reliability level was 0.7 using Cronbach Alpha Statistic. Systematic sampling was used to select the participants. The sample comprised fifty school heads from junior secondary schools and twelve school heads from senior secondary schools. Data were analysed using a computer package known as the Statistical Package for Social science (SPSS) version 22. The findings of the study showed that leadership is no longer a one man's show but, a professional work of everyone in the school. Based on the findings of the study it was recommended that for schools to be successful, they should practice a shared leadership model.
\end{abstract}

Keywords: Leadership, Shared leadership, Professional, Development 


\section{Introduction}

The concept of school leadership has now been transformed from the traditional style to one that involves other stakeholders. The traditional school leadership adopted the top-down approach where a leader is expected to be master of everything. Perhaps by virtue of his/her position the school leader was expected to lead his/her subordinates, make key decisions, motivate and inspire his /her followers (MacNeil \& McClanahan, 2005). As the world around us changes so was the school leadership style. Leading schools has now become more complex and difficult for the "know all" school leaders. Having seen that it is cumbersome for a single person to provide for all situations it was then found fit for both leaders and subordinates to work together for effective school leadership. Pearce (2007) affirms that organisations "can no longer rely on simple notions of top-down, command and control leadership, based on the idea that workers are merely interchangeable drone" (p.355). This is a clear indication that for school improvement and school effectiveness to be sustained leadership must be shared. Shared leadership encourages individuals to achieve the set objectives and goals of an institution as a united force.

The Botswana education system has made concerted efforts since the inception of the National Policy on Education (NPE) of 1977 to enforce the concept of shared leadership practices in schools. The establishment of the Board of Governors and Parent- Teachers Association for each junior secondary was to assist in the management of schools (Republic of Botswana, 1990). The philosophy of shared leadership was strengthened in the Revised National Policy on Education of 1994, where school heads were encouraged to work collaboratively with teachers and parents in the governing of schools. This was to make known to the conservative school heads that instructional leadership is a shared undertaking. As Lambert (2002) posits leadership is a professional work of everyone in the school. Everyone must be involved in the running of schools nowadays, whatever position he/she holds in the school. There is talent within the school community that administrators can tap from. Wallace (2001) points out that school heads have to be leaders of learning institutions who can develop a team that is capable of delivering effective instruction. The question is; Do school heads of Botswana secondary schools believe in sharing leadership with other stakeholders?

\subsection{Problem statement}

One of the Botswana education system's primary goals is to produce the best possible and most appropriate high quality, cost-effective, secondary education by ensuring that there is optimum management of schools where new ideas and changes can be handled quickly and efficiently at school level (Mawela, 1993 cited in Mphale, 2000). In an effort to achieve this goal, the Ministry of Education and Skills Development encourages schools to establish cluster school management teams, Parents and Teachers Associations (P. T. As) and Student Representative Councils (S. R. C). This is to improve the standard of school governance and reduce dissatisfaction among teachers, parents and students. Despite the Ministry of Education and Skills Development's effort, there are numerous cases of poor governance, low quality management, intolerance of shared leadership among the school administrators and 
lack of parental involvement (Republic of Botswana, 2008). If this persists, the schools might not be easily governed, low teachers' morale and students indiscipline may be the order of day. Therefore, the ministry's endeavour to make leadership a shared responsibility will not be realised. It is against this background that a study was conducted to investigate the school heads perception about shared leadership.

\subsection{Significance of the study}

The challenge for school leaders to sustain positive learning environment and good governance are a burden in management of schools today. It has now become more difficult for a single individual to possess all leadership skills for the smooth running of the schools. The importance of shared school leadership to improve performance and governance has been in the educational forum for the past decade. Shared school leadership has become an alternative to the top-down, command and control leadership. The study envisages to assist the policy makers, school heads, teachers and other stakeholders in the field of education to realise the importance of shared leadership. The findings of the study provide additional information regarding shared leadership in Botswana secondary schools.

\subsection{Purpose of the study}

Leadership is an important component that affects the existence of every institution. The success and failure of organisations depends largely on the type of leadership. School communities are entitled to participate in decision-making on matters that will affect them. For the school communities to share a goal, have a common culture, be committed to the ethos of the school and share responsibilities and accountability shared leadership should be practised. The purpose of the study was to investigate Botswana secondary school heads' perception on shared leadership.

\subsection{Research questions}

(a) What are school heads' perceptions about shared leadership?

(b) How do school heads respond to shared leadership practices?

(c) How can the problem of lack of shared leadership (if any) be alleviated in schools?

\section{Literature Review}

Today's school leadership practices are multi-faceted. The school heads are expected to establish a sustainable learning environment for both teachers and students. They are duty bound to be instructional leaders for the success of their schools. As school leadership has now become more complex than before. It has become difficult for a single person to possess all the skills, attitudes and knowledge required for effective school improvement (Elmore, 2000; Wallace, 2001). The success and failure of any school depends heavily on the type of leadership that exists in that school. Research has revealed that where there is interactive process among individuals in an institution productivity and good performance prevail (Hughes, 2013; Harris, 2008). Leadership has now become a professional work of everyone in the school (Lambert, 2002). Where there is active participation in the running of a school 
by school heads, teachers, ancillary staff, students and parents, school improvement is sustained(Harris, 2008; Baker, 2011).

Schools administration world-wide has shifted from the one man's show to everyone business. The complexity of the school leadership has called for shared leadership. Shared leadership is sometimes described in different ways. It is known by some scholars as distributed leadership, partnership-as-leadership and community of leaders (MacNeil \& McClanahan, 2005; Harris, 2008). The description above makes what can be termed a partnership model. The emphasis being that shared leadership is a partnership where all education stakeholders are expected to take part in school governance. Carson, Tesluk and Marrone (2007) maintain that shared leadership is "a team property whereby leadership is distributed among team members rather than focused on a single designated leader" (p.1217). It is on the basis of this assumption that where there is shared leadership all stakeholders share responsibility and accountability (Fullan, 2005). Carson, Tesluk and Marrone (2007) identify some of the benefits of shared leadership as; increasing group solidarity, reduction in misunderstanding among group members and increasing level of trust among group members.

Scholars suggest that there are five requirements or principles for the shared leadership model to be effective. According to Wallace (2011) and MacNeil and McClanahan (2005) the five principles include: balance of power among the team, a shared goal, shared responsibility, respect for personhood and working together in complex situations. The fulfilment the requirements/principle can make work easy for the school heads because teachers will have seen that they valuable and their contributions are taken on board by the school leadership. With shared leadership model everyone is shareholder in the affairs of an organisation. Having shared goal, shared responsibility and accountability, sense of ownership, respect for others skills and ideas and working collaboratively schools can accomplish their goals and objectives (Moxley, 2002 cited in MacNeil \& McClanahan, 2005). It can be assumed that one of the solutions to problems of poor students' academic performance, indiscipline, moral decadence, low teachers morale and low productivity is shared leadership model/ partnership model.

In Botswana the concept of shared leadership model came into play in the 1970's when the National Policy on Education of 1977 recommended the establishment of Parents Teachers Associations and Board of Governors. Some of the roles of the two bodies were to "assist in the management of the schools and provide a forum for interaction with the community concerning such problems as student discipline or poor school performance" (Republic of Botswana 1990, p.29). The school heads are encouraged through the RNPE (1994) to form mini-administrative structures for the smooth running of schools. Shared responsibility is enshrined in recommendation 105 of the RNPE of 1994 which states that the "Head as instructional leader, together with the deputy school head and senior teachers, should take major responsibility for the in-service training for teachers within the schools through regular observation of teachers and organisation of workshops, to foster communication between teachers on professional matters and address weaknesses." (p.47). This is a renewed emphasis on shared leadership/partnership model. 
Despite the Botswana government effort to make education an agent for national development and economic growth, there has been a public outcry in Botswana regarding a decline in students' academic performance, alarming rate of students' indiscipline, teachers misconduct, poor governance and satanic practices in secondary schools (Moeng, 2014; Keakabetse, 2012; Lekula, 2014). These escalating social ills make the Botswana secondary schools ungovernable. Barth (1990) cited in MacNeil \& McClanahan (2005) believes that for the success of schools, School Heads should develop a community of leaders by openly articulating the goal, relinquishing decision-making authority to teachers and involve teachers before decisions are made. With the escalating social ills in Botswana secondary schools, the researcher is tempted to ask few questions Is it because the school leadership is still stuck to the top-down approach style of leadership in spite of the recommendations outlined in the Revised National Policy on Education of 1994? Do Botswana secondary school Heads matter on issues of shared leadership? It was the intension of this research to find answers to some of these questions.

\section{Research Methodology}

The study used a quantitative approach and adopted a survey research design. The sample comprised of a total of 62 school heads from Botswana secondary schools from a population of 258. Systematic sampling was used to select the respondents from both senior and junior secondary schools in Botswana. Creswell (2005) describes systematic sampling as a procedure where every "nth" member in the population is chosen until the desired sample size is achieved. To reduce any possible bias creeping in, the researcher selected the first respondent at random. Then, the researcher selected the fourth name of the school head from the 258 secondary school heads arranged alphabetically. Systematic sampling allows the researcher to add a systematic element into the random selection of informants. This was to give all respondents the same probability of selection. The main advantage of using systematic sampling is its simplicity and convenience (Brink, Walt, \& Rensburg, 2014).

\subsection{Data collection}

Data was collected through the use of a questionnaire. Questions were both open-ended and closed items. The questionnaire was piloted using school heads who did not participate in the main research. Piloting was done for purposes of checking that all questions and instructions are clear and to remove any ambiguous items which may not yield usable data. After the corrections were made a final copy was produced for the main research. The questionnaire was preferred because it encourages greater honesty and that respondents have time to give thoughtful answers (Cohen, Manion, \& Morris, 2007). The closed-ended items design was based on a 5 point Likert scale. The respondents were to show their level of agreement by choosing either: Strongly Agree, Agree, Strongly Disagree, Disagree or Not sure. The questionnaire was divided into two sections. Section A was on demographic information and section B sought views of the informants on shared leadership. The researcher administered 56 questionnaires in the nearby schools. Six questionnaires were posted to the school heads in remotest areas of the country; and after completed they were mailed back to the researcher. The response rate was $62(100 \%)$. 


\subsection{Validity and Reliability}

The importance of reliability and validity of the research findings cannot be overemphasised. The trust worthiness and authenticity of data depends on reliability and validity of the measuring instruments. If the instrument functions consistently and accurately by yielding the same results, and the findings are true and accurate then the instrument is well designed (Golafshani, 2003; Creswell, 2005; Brink, Walt, \& Rensburg, 2014). Three colleagues from the faculty of education validated the questionnaire. The reliability coefficient was ascertained by using Cronbach Alpha Statistic which ended being 0.81.

\subsection{Data analysis}

Data analysis adopted a computer package normally used for positivist research known as the Statistical Package for Social science (SPSS) version 22. Before the information was fed into the computer certain things were carried out. This was in accordance with an advice by Cresswell (1994) cited in Monyatsi (2001). Firstly, it was decided that errors that might have occurred during the study be noted and eliminated. Secondly, questionnaires which were returned were counted and numbered. Thirdly, it was checked if all questions were answered. After having completed the above exercises the data was ready for SPSS. The Likert scale analysis followed Cohen, Manion, and Morris, (2007) descriptive approach of working with the frequencies and percentages of the levels of agreement and disagreement of the informants. Thus the analysis was numerical. Ary, Jacob, Sorenson and Walker (2010) suggest that data analysed numerically are easy to understand, summarise and present a clear picture to the study. As for open - ended questions themes were used. This was to make the data more meaningful and understood (Wellman, Kruger, \& Mitchell, 2012).

\section{The Results}

The findings generally indicate that the school heads are aware of shared leadership model and majority always practice it. However, very few respondents show the feel of losing power if they involve other stakeholders on every issue that affects the stakeholders. The results of the study are shown in table 1 below. 


\section{Macrothink}

Table 1. School Heads perception about Shared Leadership in schools.

\begin{tabular}{|c|c|c|c|c|c|c|c|c|c|c|}
\hline \multirow[b]{2}{*}{ Statement } & \multicolumn{10}{|c|}{ Participants Responses } \\
\hline & S/D & $\%$ & D & $\%$ & $\mathbf{A}$ & $\%$ & S/A & $\%$ & $\mathbf{N} / \mathbf{S}$ & $\%$ \\
\hline \multicolumn{11}{|l|}{ Perceptions about shared leadership model } \\
\hline 1. Improves school governance. & 2 & 3 & 1 & 2 & 28 & 45 & 31 & 50 & 0 & 0 \\
\hline 2. Promotes culture of respect for one another. & 2 & 3 & 0 & 0 & 25 & 40 & 35 & 57 & 0 & 0 \\
\hline 3. Enhances sense of ownership among staff. & 0 & 0 & 1 & 2 & 17 & 27 & 44 & 71 & 0 & 0 \\
\hline $\begin{array}{l}\text { 4. Encourages staff to participate in decision- } \\
\text { making process. }\end{array}$ & 1 & 2 & 0 & 0 & 36 & 58 & 25 & 40 & 0 & 0 \\
\hline 5. Promotes transparency and accountability. & 2 & 3 & 0 & 0 & 47 & 76 & 13 & 21 & 0 & 0 \\
\hline 6. Creates a friendly school environment & 1 & 2 & 1 & 2 & 30 & 48 & 30 & 48 & 0 & 0 \\
\hline $\begin{array}{l}\text { 7. Helps the school administration make the } \\
\text { right choices and decisions }\end{array}$ & 2 & 3 & 2 & 3 & 23 & 37 & 35 & 57 & 0 & 0 \\
\hline $\begin{array}{l}\text { 8. Improves collaboration between the school, } \\
\text { parents and community }\end{array}$ & 2 & 3 & 1 & 2 & 26 & 42 & 33 & 53 & 0 & 0 \\
\hline 9. Reduces misunderstanding among the group & 1 & 2 & 0 & 0 & 31 & 50 & 30 & 48 & 0 & 0 \\
\hline 10. Facilitates increased level of trust. & 1 & 2 & 0 & 0 & 13 & 21 & 48 & 77 & 0 & 0 \\
\hline \multicolumn{11}{|l|}{ The benefits of shared leadership model } \\
\hline 11. Accomplishment of a common goal & 2 & 3 & 1 & 2 & 21 & 34 & 38 & 61 & 0 & 0 \\
\hline 12. Good school governance. & 3 & 5 & 0 & 0 & 38 & 61 & 21 & 34 & 0 & 0 \\
\hline 13. Equal partnership amongst stakeholders. & 0 & 0 & 3 & 5 & 25 & 40 & 34 & 55 & 0 & 0 \\
\hline 14. Common culture. & 1 & 2 & 2 & 3 & 52 & 84 & 7 & 11 & 0 & 0 \\
\hline 15. Staff acquires leadership skills. & 0 & 0 & 1 & 2 & 43 & 69 & 18 & 29 & 0 & 0 \\
\hline 16. Shared responsibility and accountability. & 2 & 3 & 1 & 2 & 18 & 29 & 41 & 66 & 0 & 0 \\
\hline 17. Friendly school learning environment. & 3 & 5 & 0 & 0 & 20 & 32 & 39 & 63 & 0 & 0 \\
\hline 18. Group solidarity. & 3 & 5 & 0 & 0 & 30 & 48 & 29 & 47 & 0 & 0 \\
\hline
\end{tabular}

Table 1 above reflects how school heads perceive shared leadership as practised in their schools. Sixty (97\%) respondents viewed the practices as useful because they promotes culture of respect for one another and promotes transparency and accountability. Two (3\%) were in disagreement with the statements. Sixty-one (98\%) respondents believed that shared leadership enhances sense of ownership among staff, encourages staff to participate in decision- making process and reduces misunderstanding among the group members. One (2\%) 
informant disagreed with statements. Fifty-nine (95\%) were of the opinion that shared leadership creates a friendly school environment, improves school governance, improves collaboration between the school, parents and community, helps the school administration make the right choices and decisions; while three (5\%) disagreed with the above statements.

Regarding the benefits fifty-nine (95\%) of the respondents believed that shared leadership makes group members to have a common goal, common culture, shared responsibility, good school governance, a friendly school learning environment and group solidarity. Three (5\%) disagreed with above statements. Concerning staff been able to acquire leadership skills sixty-one (98\%) informants agreed with the statement, while one $(2 \%)$ disagreed. When the respondents were asked about practicing the shared leadership on every matter that needs stakeholders input, fifty-nine (95\%) respondents indicated that they practise school leadership model on any matter that affects the stakeholders, while three $(5 \%)$ respondents showed their discontent on the basis that constant consultation delays progress. Generally the respondents (97\%) feel shared leadership practices add value to school governance as stakeholders develop a sense of belonging. It is just a few respondents (3\%) who seem to be adamant that the practices encourage lawlessness, disrespect for the authority and decision-making takes long time.

In open-ended questions the respondents indicated that the implementation of shared leadership practices has challenges. Sixty (97\%) respondents showed that they face reluctance by junior staff members to carry out delegated duties with the belief that they are being used. As a result it takes a long time for some decisions to be taken. Another challenge mentioned is resistant to change. Sixty-one (98\%) of the respondents showed that teachers are not willing to accept change, while one $(2 \%)$ questioned the accountability of junior staff members.

\section{Discussion}

The research findings indicate that the school heads value shared leadership practices. The respondents perceive shared leadership as the most important principle in enhancing good school governance, promotes transparency and accountability, enhances a sense of ownership among staff and encourages staff to participate in decision- making process in Botswana secondary schools. The respondents also emphasised that shared leadership practices create a better learning environment, build trust among the stakeholders, staff members share the same goal and culture. Duignan and Bezzina (2006) concur that schools which practise shared leadership model create and maintain collaboration, shared vision, shared goals and a conducive environment for teaching and learning. Shared leadership is about bringing every education stakeholder on board, where ideas are shared, skills acquired and members of the group are empowered. Goldsmith (2010) affirms that shared leadership involves maximising all of the human resources in an institution by empowering them and been given an opportunity to lead in their area of expertise.

With regard to school heads response to shared leadership practices the respondents indicated that the school administrators are supportive in providing positive school climate. Having a positive climate may encourage teachers, ancillary staff and students to feel more committed 
to the school success in academic performance. According to Pickerall, Evans, Hughes and Hutchinson (2009) positive school climate improves achievement and a sense of belonging. This suggests that a positive school climate empowers, engages and motivates all stakeholders to do what is expected of them. The respondents also revealed that the school heads delegate some of their duties to junior staff members and share the decision-making process. This makes the school heads less managerially burdened and can devote some their time to solve pressing issues. Staff members would feel valued and be committed to instructional improvement. Conger and Pearce (2003) confirmed that by sharing decision-making authority with colleagues in organisations make them engaged in and committed to what they are doing.

Responding to alleviating the problem of lack of shared leadership in schools the respondents suggested several ways. They suggested that school heads can foster shared leadership through working collaborate with students, teachers and parents. The respondents felt that working collaboratively with all stakeholders encourages collective responsibility, sense of ownership, accountability and commitment in implementing policies. This is affirmed by Hughes and Pickerall (2013) that effective shared school leadership practice is one that thinks partnership, ensures shared practice, commits shared responsibilities and builds respect. The respondents also emphasized the issue of involving all stakeholders in decision-making process as a way of enhancing accountability and responsibility. This approach is recommended by Pickerall, Evans, Hughes and Hutchinson (2009) when saying shared leadership works well when all stakeholders share responsibility and accountability. Some of the practices the informants felt the school heads could do include; mentoring, team building, induction, addressing cultural issues, changing the mindset of staff members and liaising with committees in the community. Establishment of Parents and Teachers Associations (P.T.As), Parents, Teachers and Students Associations P.T.S.As) and School Intervention Teams (SIT) were some of the approaches where leadership can be shared and cultivated in others. Harris (2008) attests that through capacity building school improvement can be sustained.

With regard to challenges face by school heads in implementing shared leadership, the respondents reported reluctance by junior staff members to carry out shared responsibilities on the basis of being used by school administrators. With this belief it would be difficult to implement shared leadership practices. The school heads has to transform the teachers' beliefs for the success of shared leadership (Gallison, 2000).

\section{Conclusions and recommendations}

The study has revealed that shared leadership is practiced in majority Botswana secondary schools. Teachers, parents and students are actively involved in decision making processes, given responsibilities, encouraged to be committed to and own the schools policies. The principle of shared leadership in Botswana's secondary school context refers to the partnership between teachers, parents, students, government and non-governmental organisations whose objective is to achieve educational goals (Republic of Botswana, 1994). As revealed in the study, in this partnership all stakeholders share responsibility, accountability and ownership. This view is also shared by scholars who happen to perceive 
shared leadership practices as processes of sharing responsibilities, sharing ideas, working as a team, promoting ownership and accountability (Carson, Tesluk, \& Marrone, 2007; Harris, 2008). Gone are the days when one individual irrespective of the talent he has can be the master of all. Schools no longer rely on top-down, command and control leadership (Pearce, 2007). The assumption is that everyone in the school has the potential to be a leader in his/her area of expertise. It is believed by respondents that through shared leadership the school's goals can be achieved. Duignan and Bezzina (2006) affirm that schools with shared leadership create and maintain a shared vision, shared goals and promote staff development. Botswana secondary schools through education policies, innovations and other statutes are encouraged to reap the benefits of shared leadership for effective teaching, learning and development. Although majority of Botswana school heads have indicated that they are aware of shared leadership and practise it; the implementation is faced with challenges. Challenges such conflict between senior management and subordinates and resistant to change by both senior managers and teachers have been reported by the respondents. The findings of the informs stakeholders that creating a meaningful purpose, commitment to team performance, team member accountability and responsibility are the corner stone of successful shared leadership (Locke, 2003). Basing on the findings, the study recommends that:

- School heads should lead in practicing shared leadership activities.

- School heads, teachers and students should be equal partners on matters of school governance.

- Parents' involvement in the education of their children should be a priority.

- Roles and responsibilities should reflect broad involvement, collaboration, collective responsibilities and commitment.

- Staff members, students and other stakeholders should always reflect on their roles to enhance share leadership model.

\section{Acknowledgement and Sponsoring information}

I would to acknowledge Dr. Mavis B. Mhlauli for proof reading the article before publication. This is a self-sponsored article.

\section{References}

Ary, D., Jacobs, C. L., Sorensen, C. \& Walker, D.A. (2010). Introduction to Research in Education (8th ed.). Australia: Wadsworth Cengage Learning.

Baker, T. (2011). Doing school Research. New York: McGrawhill.

Brink, H., Walt, C., \& Rensburg, G. (2014). Fundamentals of Research Methodology for Healthcare Professionals (3rd ed.). Cape Town: Juta and Company Ltd

Carson, J. B., Tesluk, P. E., \& Marrone, J. A. (2007). Shared Leadership in Teams: An investigation of antecedent conditions and performance. Academy of Management Journal, 50(5), 1217-1234. http://dx.doi.org/10.2307/AMJ.2007.20159921

Cohen, L., Manion, L., \& Morris, K. (2007) (6th ed.). Research Methods in Education. London: Routledge. 
Conger, J., \& Pearce, C. (2003). A Landscape of Opportunities: Future Research in Shared Leadership. Thousand Oaks: Sage Publications.

Creswell, J. (2005). Educational Research: planning, conducting and evaluating qualitative and quantitative research. New Jersey: Pearson Education Ltd.

Duignan, P. \& Bezzina, M. (2006). Distributed Leadership: The theory and the Practice. CCEAM Annual Conference (pp. 1-22). Cyprus: CCEAM.

Elmore, R. (2000). Building a new structure for school leadership. Washington: Albert Shanker Institute.

Fullan, M. (2005). Leadership and Sustainability: System thinkers in action. Thousand Oaks: Corwin Press.

Golafshani, Nahid, (2003). Understanding Reliability and Validity in Qualitative Research. The Qualitative Report, 8(4), 597-607. [Online] Available: http://www.nova.edu/ssss/QR/QR8-4/golafshani.pdf (December 4, 2003).

Goldsmith, M. (2010). Sharing Leadership to Maximize Talent. [Online] Available: https://hbr.org/2010/5/sharing-leadership-to-maximize/

Harris, A. (2008). Distributed Leadership. Lancaster: CEL.

Hughes, W. (2013). School climate and leadership. Milwauke: Alverno College.

Keakabetse, B. (2012, October19). Maun Senior Secondary School closed. Mmegi, p.6

Lambert, L. (2002). Leadership capacity for lasting school improvement. Alexandra: Association for Supervision and Curriculum Development.

Lekula, M. (2014, November 6). Police probe students' riot. Botswana Daily News, p.2

Locke, E. (2003). Leadership starting at the top: Shared Leadership; Reframing the hows and whys of leadership. Thousand Oaks: Sage Publication.

MacNeil, A., \& McClanahan, A. (2005). Shared Leadership. [Online] Available: http://cnx.org/content/m12923/latest/

Moeng, G. (2014, March 24). Okavango MP Fights for failed Shakawe Students. Mmegi, p.2

Monyatsi, P. P. (2001). An investigation of the effectiveness of the current teacher appraisal system as practiced in Botswana secondary schools. (PhD Thesis). UNISA, Pretoria South Africa

Mphale, L. M. (2000). An Investigation of Teachers, Board of Governors, School Management Advisers and Ancillary staff views, perceptions and attitudes towards staff development programmes established in community junior secondary schools of Botswana. (Masters of Art in Educational Management Dissertation). University of Bath, Bath United Kingdom.

Pearce, C. (2007). The future of leadership development: The importance of identity, 


\section{Macrothink}

Journal of Studies in Education

ISSN 2162-6952 2015, Vol. 5, No. 2

multi-level approaches, self-leadership, physical fitness, shared leadership, networking, creativity, emotions, spiritual and on-boarding processes. Human Resource Management Review, 17(4), 355-359. http://dx.doi.org/10.1016/j.hrmr.2007.08.006

Pickeral, T., Evans, L., Hughes, W., \& Hutchinson, D. (2009). School Climate Guide for District, Policy Makers and Educational Leaders. New York: Centre for Social and Emotional Education.

Republic of Botswana (2008). Towards a Knowledge Society-Tertiary Education Policy. Gaborone: Government Printer.

Republic of Botswana (1994). The Revised National Policy on Education. Gaborone: Government Printer.

Republic of Botswana (1990). Improving the Quality of Basic Education in Botswana. Gaborone: Government Printer.

Republic of Botswana (1977). The National Policy on Education. Gaborone: Government Printer.

Wallace, M. (2001). Sharing Leadership Through Team Work: A justifiable risk? Educational Management and Administration, 29(2), 153-167. http://dx.doi.org/10.1177/0263211X010292002

Wellman, C., Kruger, F., \& Mitchell, B. (2012). Research Methodology (3rd ed.) Cape Town: Oxford University Press. 